\title{
THE RELATIONSHIP OF PARENTING STYLES AND THE INCIDENT OF OVERWEIGHT AMONG PRE-SCHOOL CHILDREN AGED 3-5 YEARS IN THE WORK AREA OF PUSKESMAS KALIDONI PALEMBANG
}

\author{
Hardiati, Fatmalina Febry \\ Department of Nutrition, Public Health Faculty Sriwijaya University
}

\begin{abstract}
Obesity has become a global health problem in the world. The impact of obesity is a degenerative disease. The style of family care is one of the factors that influence the occurrence of obesity in children. The purpose of this study was to determine the relationship between family care style with obesity in preschool children aged 3-5 years. This study uses a crosss-sectional design with a total of 143 preschool children aged 3-5 years using Cluster Sampling Techniques. Research shows that there is a relationship between parental supervision when watching television $(p=0.043)$ and parental physical activity patterns $(p=0.000)$, while the most dominant variable is the parental physical activity pattern with a PR value of 15.896. School is influenced by parental supervision when watching television and parental physical activity patterns. It hopes that all parties can make efforts to prevent obesity in children by increasing physical activity of children such as buying sports equipment and inviting children to exercise and conduct more stringent supervision when children watch television, play games or gadgets.
\end{abstract}

Keywords: Family parenting style, obesity, preschool children

\section{HUBUNGAN GAYA PENGASUHAN KELUARGA DENGAN KEJADIAN KEGEMUKAN DI WILAYAH KERJA PUSKESMAS KALIDONI KOTA PALEMBANG}

\begin{abstract}
ABSTRAK
Kegemukan telah menjadi masalah kesehatan global di dunia. Dampak yang ditimbulkan dari kegemukan adalah gangguan penyakit degeneratif. Gaya pengasuhan keluarga merupakan salah satu faktor yang mempengaruhi terjadinya kegemukan pada anak. Tujuan penelitian ini untuk mengetahui hubungan antara gaya pengasuhan keluarga dengan kegemukan pada anak pra sekolah usia 3-5 tahun. Penelitian ini menggunakan desain cross sectional dengan jumlah sampal 143 orang anak pra sekolah usia 3-5 tahun dengan menggunakan teknik pengambilan sampel Cluster Sampling. Hasil penelitian menunjukkan bahwa ada hubungan antara pengawasan orang tua ketika menonton televisi ( vvalue $=0,043$ ) dan pola aktivitas fisik orang tua (pvalue $=0,000$ ), sedangkan variabel yang paling dominan adalah pola aktivitas fisik orang tua dengan nilai PR sebesar 15,896. Kegemukan pada anak pra sekolah dipengaruhi oleh pengawasan orang tua ketika menonton televisi dan pola aktivitas fisik orang tua. Diharapkan agar semua pihak dapat melakukan upaya pencegahan kegemukan pada anak dengan meningkatkan aktivitas fisik anak seperti membeli peralatan olahraga dan mengajak anak berolahraga serta melakukan pengawasan yang lebih ketat ketika anak menonton televisi, bermain game ataupun gadget.
\end{abstract}

Kata Kunci: Gaya pengasuhan keluarga, kegemukan, anak pra sekolah.

\footnotetext{
${ }^{1}$ Correspondece Address: Fatmalina Febry Jl. Palembang Prabumulih KM 32, Indralaya Kabupaten Ogan Ilir, Sumatera Selatan Email:_fatmalina_fkmunsri@yahoo.com
} 


\section{INTRODUCTION}

Overweight has become a global health problem in the world both in developed countries such as countries in Europe and America as well as in developing countries such as in Asia and Africa. ${ }^{1}$ In developed and developing countries, the prevalence of overweight children has increased. In 2016, 41 million children under the age of 5 were overweight. It estimates that obesity rates continue to increase to 70 million children in 2025. Overweight is currently experiencing an increase in poor and developing countries, especially in urban areas. Asia is the largest contributor to the incidence of obesity in children under the age of 5 years, which is about half of that amount. ${ }^{2}$

The prevalence of obesity in children under five in Indonesia is increasing. South Sumatra Province include in 12 provinces that have overweight children problems above the national rate and the highest prevalence of overweight children after Lampung Province. ${ }^{3}$ Based on recapitulation data on the results of weighing reports based on the indicators of weight for age level in Palembang City in 2017, the total number of children with overweight in the city of Palembang as many as 1045 people with the highest obesity rate in infants are in the Kalidoni District, which is 228 cases based on weight for age indicators. There are three puskesmas in the Kalidoni area, namely Bukit Sangkal Puskesmas with a total number of 98 children affected by obesity, 109 Kalidoni Puskesmas, and 21 Sei Selincah Puskesmas.

Overweight has a high risk of developing obesity. ${ }^{4}$ In childhood, obesity can increase the incidence of type 2 diabetes mellitus (DM). Obesity in childhood also risks settling into adulthood and potentially resulting in diabetes mellitus (DM) type 2, heart disease, stroke, and others. Obesity in children aged 6-7 years can reduce the activity and creativity of children so that children will tend to be lazy because they are overweight. ${ }^{5}$

Davison and Birch 2001 developed a model about predictors of obesity in children. The risk factors for obesity in children moderateby characteristics of the child, such as age, sex, and susceptibility to weight gain. The development of child risk factors shape by parenting styles and family characteristics, such as peer and sibling interactions, parental supervision when children watch television, parental activity patterns, and parental encouragement of child activities. ${ }^{6}$

Pre-school children aged 3-5 years have a tend to imitate older family members, especially siblings. ${ }^{7}$ According to Yang and Ochiai, the number of siblings is a related factor that affects the risk of obesity in preschool children aged 3-5 years. ${ }^{8,9}$ There is a relationship between the factors accompanying parents when watching television with obesity in infants, and parental activity patterns significantly increase children's activity. ${ }^{10,11}$ Several studies have found that when parents support the physical activity of children, it will improve the physical fitness of children, as well as overweight children. ${ }^{12}$

The purpose of this study is to analyses the relationship between family parenting style with the incidence of obesity in preschool children aged 3-5 years.

\section{METHOD}

The study design used a cross-sectional study. The population in this study is preschool children aged 3-5 years in the working area of Kalidoni Health Center in Palembang City. Samples taken in this study were 143 people using the Cluster Sampling method. Primary data in this study are the characteristics of children and parents, interactions with peers and siblings, parental 
supervision when children watch television, parental activity patterns and parental encouragement of children's activities and anthropometric data of children. Questionnaires are used to obtain information in the form of characteristics of children and parents and parental supervision when children watch television are prepared and have been tested for validity and reliability. Interaction questionnaire between children with peers or siblings using the Peer Norms Scale, parental activity patterns using the Global Physical Activity Questionnaire (GPAQ), parents' encouragement of children's activities using The Activity Support Scale for Multiple Groups (ACTS-MG) questionnaire. Anthropometric measurements to determine the nutritional status of the respondent's children using digital scales and microtoise measuring devices. Data collection was done by interviewing the mother using a questionnaire and anthropometric measurements in children.

Data is processed by editing, coding, data entry, and data settings. Data analysis consisted of univariate, bivariate, and multivariate analyses. Univariate analysis was performed to study the frequency distribution of characteristics of children and parents as well as the dependent and independent variables. Bivariate analysis was conducted to analyze the relationship between two variables. The bivariate test used in this study (hypothesis test) was a chi-square test using a 0.05 significance level and risk estimation using a Prevalence Ratio (PR) at Confidence Interval $(95 \% \mathrm{CI})$. Multivariate analysis is used to see the independent variables that most influence the dependent variable. In this study, using multivariate analysis with multiple logistic regression types predictive models.

\section{RESULTS}

\section{Univariate Analysis}

The frequency distribution of characteristics of pre-school children and parents in the working area of the Kalidoni Public Health Center is as follows:

Table 1. Frequency Distribution of Characteristics of Children and Parents

\begin{tabular}{lcc}
\hline \multicolumn{1}{c}{ Variable } & Frequency (n) & Percentage (\%) \\
\hline Age of children & & \\
3 Years & 61 & 42,7 \\
4 Years & 54 & 37,8 \\
5 Years & 28 & 19,6 \\
Gender & & \\
Female & 71 & 49,7 \\
Male & 72 & 50,3 \\
Birth Order & & \\
The First Child & 46 & 32,2 \\
Not The First Child & 97 & 67,8 \\
Mother's Educational Level & & \\
Elementry School & 3 & 2,1 \\
Middle School & 13 & 9,1 \\
High School & 87 & 60,8 \\
$\quad$ College & 40 & 28,0 \\
Mother's work Status & & \\
$\quad$ Work & 8 & 5,6 \\
$\quad$ Does not Work & 135 & 94,4 \\
\hline
\end{tabular}

Based on Table 1 above, the majority of children were 3 years old $(42.7 \%)$, and the majority of children were not the first child $(67.8 \%)$. Based on the characteristics of parents, the majority of mothers have a high school education (60.8\%) and are unemployed (94.4\%). The detailed univariate analysis results show in the table below: 
Table 2. Dependent and Independent Variable Frequency Distribution

\begin{tabular}{lcc}
\hline \multicolumn{1}{c}{ Variable } & Frequency(n) & Percentage (\%) \\
\hline Dependent Variable & & \\
\hline Nutritional Status & 22 & 15,4 \\
$\quad$ Overweight & 121 & 84,6 \\
$\quad$ Normal & & \\
\hline Independent Variable & 70 & 49,0 \\
\hline Interaction of Peers or Siblings & 73 & 51,0 \\
$\quad$ Weak & & \\
$\quad$ Strong & 46 & 32,2 \\
Parental Control When Watching Television & 97 & 67,8 \\
$\quad$ Not Good & & 18,2 \\
$\quad$ Good & 26 & 81,8 \\
Parent's Physical Activity Pattern & 117 & 47,6 \\
$\quad$ Low & & 52,4 \\
$\quad$ Enough & 68 & \\
Parent's Encouragement of Children's Activites & 75 & \\
$\quad$ Low & & \\
$\quad$ High & & \\
\hline
\end{tabular}

Based on Table 2 above, it shows that overweight children are $15.4 \%$. The majority of children have a strong peer or sibling interactions $(51.0 \%)$, good supervision from parents when watching tv $(67.8 \%)$, have sufficient physical activity patterns $(81.8 \%)$, and high encouragement from parents to the child's activity $(52.4 \%)$.

\section{Bivariate Analysis}

The purpose of doing a bivariate analysis is to see the relationship between the independent variable and the dependent variable. For bivariate analysis in this study using The Chi-Square Test, the results of the study can see in the following table:

Table 3. Relationship of Family Care Style with Nutritional Status Pre-School Children Aged 3-5 Years

\begin{tabular}{|c|c|c|c|c|c|c|}
\hline \multirow{3}{*}{ Variable } & \multicolumn{4}{|c|}{ Nutritional Status } & \multirow{3}{*}{$P$-value } & \multirow{3}{*}{ PR $(95 \% \mathrm{CI})$} \\
\hline & \multicolumn{2}{|c|}{ Overweight } & \multicolumn{2}{|c|}{ Normal } & & \\
\hline & $\mathbf{n}$ & $\%$ & $\mathbf{n}$ & $\%$ & & \\
\hline \multicolumn{7}{|l|}{ Child Gender } \\
\hline Female & 13 & 18.3 & 58 & 81.7 & 0.465 & $0.683(0.312-1.495)$ \\
\hline Male & 9 & 12.5 & 63 & 87.5 & & \\
\hline \multicolumn{7}{|l|}{ Mother's Education } \\
\hline Low & 1 & 6.2 & 15 & 93.8 & 0.467 & $0.378(0.054-2.624)$ \\
\hline High & 21 & 16.5 & 106 & 83.5 & & \\
\hline \multicolumn{7}{|l|}{ Mother's Work Status } \\
\hline Do Not Work & 2 & 25.0 & 6 & 75.0 & 0.356 & $1.688(0.476-5.988)$ \\
\hline Work & 20 & 14.8 & 115 & 85.2 & & \\
\hline \multicolumn{7}{|c|}{ Interaction of Peers or Siblings } \\
\hline Weak & 12 & 17.1 & 58 & 82.9 & 0.735 & $1.251(0.578-2.710)$ \\
\hline Strong & 10 & 13.7 & 63 & 86.3 & & \\
\hline \multicolumn{7}{|l|}{ Parental Control When } \\
\hline Watching Television & 12 & 26.1 & 34 & 73.9 & & $2.530(1.181-5.423)$ \\
\hline $\begin{array}{l}\text { Not Good } \\
\text { Good }\end{array}$ & 10 & 10.3 & 87 & 89.7 & 0.028 & \\
\hline \multicolumn{7}{|c|}{ Parent's Physical Activity } \\
\hline Pattern & 14 & 53.8 & 12 & 46.2 & & $7.875(3.692-$ \\
\hline $\begin{array}{l}\text { Low } \\
\text { Enough }\end{array}$ & 8 & 6.8 & 109 & 93.2 & 0.000 & 16.799) \\
\hline $\begin{array}{l}\text { Parent's Encouragem } \\
\text { Children's Activites }\end{array}$ & 8 & 11.8 & 60 & 88.2 & 0.363 & $0.630(0.282-1.409)$ \\
\hline $\begin{array}{l}\text { Low } \\
\text { High }\end{array}$ & 14 & 88.2 & 61 & 81.3 & & \\
\hline
\end{tabular}


Based on Table 3 above, it is known that there is a relationship between parental supervision when watching television $(\mathrm{p}=0.028)$ and parental physical activity patterns $(p=0,000)$ with obesity in preschool children aged 3-5 years. There is no relationship between the sex of the child $(\mathrm{p}=0.465)$, mother's education $(\mathrm{p}=0.467)$, mother's work status $(\mathrm{p}=0.356)$, peer or sibling interaction $(\mathrm{p}=0.735)$, and parents' encouragement on children's activities $(p=0.630)$ with obesity in preschool children aged 3-5 years.

\section{Multivariate analysis}

Multivariate analysis is used to see the independent variables that most influence the dependent variable. In this study using multivariate analysis with multiple logistic regression types predictive models. The results of multivariate analysis of this study can be seen in the following table:

\section{Table 4. Multivariate Analysis of Overweight in Pre-school Children}

\begin{tabular}{llll}
\hline Variable & OR & 95\% CI & P value \\
\hline Parental Control When Watching Television & 0,228 & $0,072-0,726$ & 0,012 \\
Parent's Physical Activity Pattern & 0,051 & $0,016-0,162$ & 0,000 \\
\hline
\end{tabular}

Based on Table 4 above, there are two variables that are most related to the incidence of obesity in preschool children aged 3-5 years, namely parental supervision when watching television and the patterns of physical activity of parents. The most dominant variable was found in parental.

\section{DISCUSSION}

Obesity is overweight due to incoming energy intake more than the energy released. ${ }^{13}$ Determination of obesity in this study uses BMI for age index because, according to WHO, this is very good for determining the nutritional status of children and is also used for researching and monitoring children's growth. Achild is categorized as overweight if $\mathrm{z}$ score $>2 \mathrm{SD}$ base on BMI for age for children aged 0-60 months. ${ }^{14}$ Signs - children who are overweight are quickly tired and slow in moving and viewed from height and weight. $^{15}$

Overweight in children makes the growth and development of children less optimal. Overweight will make it difficult for children to breathe when walking or running due to shortness of breath and also become fatigued quickly so that they are not strong in carrying out activities for a long time. According to Karel, children who are overweight have a high risk of obesity. children can increase the risk of developing type 2 diabetes mellitus, heart disease, hypertension and respiratory problems. ${ }^{4}$ supervision when watching television $(\mathrm{p}=$ $0.012, \mathrm{OR}=0.228$ ), which means pre-school children with poor parental supervision had a risk of 0.228 times overweight compared to pre-school children with good parental supervision.

There is a relationship between sex and nutritional status. ${ }^{16}$ The results showed that girls more at risk of obesity compared with boys. The results of this study are in line with research conducted by Davison and Birch which found that girls are more overweight. In terms of calorie intake requirements between boys and girls at pre-school age do not experience a significant difference so that the opportunities for actual weight gain are the same. ${ }^{17}$ Due to the possibility of other factors not examined such as food intake and physical activity children that can affect obesity. Beside, the number of research results that are not clear also results in no relationship between sex with obesity in pre-school children.

The mother's education level is the main capital in the preparation of family meals, care, and child care. ${ }^{18}$ The results of this study indicate that most maternal education is high school level. Mother's education can determine how and how much the ability of mothers to choose, process food, to prepare it. Mothers with higher education 
have a tend to choose foods that are better in terms of quality or quantity. On the other hand, mothers with low education only have limited food choices based on their knowledge, so that in terms of the type or variety of food they are still very monotonous. ${ }^{19}$

Working mothers are also one of the factors causing obesity in children. Working mothers have a relationship with the incidence of obesity in children compared to mothers who do not work. ${ }^{20}$ Working mothers do not have enough time to care for and control the nutritional intake of children. This can cause nutritional disorders in children. Preschoolers should have a balanced nutritional intake so that it does not cause problems for the child's growth and development. ${ }^{21}$ Mothers who do not work have more time for their children and always feed regularly even though food is given simply. ${ }^{22}$

Peer interaction is the relationship of individuals with a group of the same age. ${ }^{23}$ Playgroups play an important role in shaping children's physical activity. The closer ties of friendship will increasingly affect the level of physical activity of children. ${ }^{24}$ The results of this study indicate there is no significant relationship between the interactions of friends or siblings with the incidence of obesity in pre-school children. In this study, more children play alone, happy to play outside the house until the afternoon even tired. This shows that there is sufficient physical activity for the child to prevent or reduce obesity.

The results of this study are in line with research conducted by Dewi, which shows that the majority of children watch television for more than 1 (one) hour. ${ }^{25}$ Most of the children spend time watching television because their parents think television is cheap entertainment because it is available at home and practice for children. ${ }^{26}$ According to Lowry, watching television is classified as the mild activity, which means it does not use much energy. Children who lack physical activity are more likely to experience obesity because the number of calories burned is less than the calories obtained from food consumed so that the potential to cause accumulation of excess fat in the body. ${ }^{27}$ Watching television for a long time can also affect a child's sleep patterns and time to play with children his age. Watching television is good enough for pre school children's learning processes, if the time used, is not excessive and there is control or supervision from parents. ${ }^{28}$

The variable of physical activity patterns of parents with obesity in pre-school children in this study is related. These results are in line with the results of research presented by Benson who said that there is a significant relationship between patterns of physical activity of parents with obesity. ${ }^{29}$ Lindsay et al. said that children with more active mothers were 2 times more likely to be active than children with mothers who were less active. When both parents are active, children will be 5.8 times more active than children with both parents who are inactive. ${ }^{30}$

Parental encouragement is an important thing. Parents have a role in maintaining children's health, exemplifying appropriate behavior in order to create better health. ${ }^{31}$ Some encouragement that parents can give to their children is direct support such as providing facilities and providing motivation. ${ }^{32}$ Based on the results of Davison, Cutting, and Birch's research, activities related to parenting practices such as parents' encouragement and support have a positive contribution to physical activity in children. ${ }^{33}$

Based on the results of logistic regression analysis, it was found that the variables most associated with the incidence of obesity in preschool children aged 3-5 years, namely the sex of the child, mother's education, mother's work, parental supervision when watching television, parental encouragement of children's activities, and Parents' physical activity patterns, but based on controlled analysis with other variables, the most dominant variable associated with obesity events in preschool children aged 3-5 years is the parent's physical activity patterns. Parents are the center of a child's life, so what parents do will be an example for their children, It shows that good or bad behavior of parents will affect children. ${ }^{34}$ The level of parental activity and activity patterns significantly increase children's activity children. 


\section{CONCLUSION}

Parenting style affects the incidence of obesity in pre-school children. Parents are the center of a child's life, so what parents do will be an example for their children, It shows that good or bad behavior of the parents will affect

\section{REFERENCES}

1. Prentice, A.M.The Emerging Epidemic of Obesity in Developing Countries. International Journal of Epidemiology. 2006; Vol.35(1): 93-9.

2. World Health Organization. Prevalence of Overweight Among Adolescents and Children. 2016. Diakses pada 13 Maret 2018, dari http://www.who.int/gho/ncd/risk_factors

3. Kementerian Kesehatan. Riset Kesehatan Dasar. Badan Penelitian dan Pengembangan Kesehatan, Jakarta.2013.

4. Karel, H., et al. Prevention of Overweight and Obesity in Childhood A Guideline for School Health Care. 2007;Vol.13(1): 24-8.

5. Syarif. Obesitas pada Anak dan Permasalahannya. Skripsi. Universitas Indonesia. 2006.

6. Davison, K.K., dan Birch, L.L. Childhood Overweight: A Contextual Model and Recommendations for Future Research. Obesity Reviews. 2001; Vol.2(3): 159-171.

7. $\mathrm{Hu}, \mathrm{J}$ et al. 2017. Who is More Likely to be Obese or Overweight Among Siblings? A Nationally

8. Yang, J. 2007. China's One-Child Policy and Kegemukan Children in the 1990s. Social Science \& Medicine. 64, 20432057.

9. Ochiai, H., et al. 2012. Number of Siblings, Birth Order and Childhood Overweight: A Population-Based CrossSectional Study in Japan. BMC Public Health. 12(766), 1-7. DOI: 10.1186/1471-2458-12-766. the child. Parents must encourage and provide time and facilities for children to do physical activity and limit sedentary activities in children.

10. Wilson, B.J. 2008. Media and Children's Agression, Fear and Altruism. The Future of Children. 18(1), 87-118.

11. Kalakanis, L.E., et al. Parental Activity as a Determinant of Activity in Obese Children. Research Quarterly for Exercise and Sport. 2001; Vol.72(3): 202209

12. Griffith, J.R., et al. Role of Parents in Determining Children's Physical Activity. World Journal of Pediatric. 2007;Vol.3(4): 265-270.

13. Kementerian Kesehatan. Riset Kesehatan Dasar. Badan Penelitian dan Pengembangan Kesehatan, Jakarta. 2010.

14. Keputusan Menteri Kesehatan. Standar Antropometri Penilaian Status Gizi. Jakarta: Direktorat Bina Gizi dan Kesehatan Ibu dan Anak. 2010.

15. Depkes RI. Klasifikasi Status Gizi Anak Bawah Lima Tahun. Keputusan Mentri Kesehatan RI Nomor: 920/Menkes/SK/VIII/2002. Jakarta: Direktorat Jendral Bina Kesehatan Masyarakat. 2005.

16. Nelson, J.A., Chiasson, M.A., \& Ford, V. 2004. Childhood Obesity in a New York City Wic Population. American Journal of Public Health. 94(3), 458-462.

17. Almatsier, S. Prinsip Dasar Ilmu Gizi. Jakarta: Gramedia Pustaka Utama. 2009

18. Suhardjo. Berbagai Cara Pendidikan Gizi. Jakarta: Bumi Aksara. 2003.

19. Karyani. I., Syarif, H., dan Fatmalina, F. Gambaran Kebiasaan Makan pada Anak Prasekolah di TK Bhakti Asuhan dan TKIT Izzhudin Palembang tahun 2009. 
Jurnal Ilmu Kesehatan Masyarakat. 2012;Vol.3(3): 182-193

20. Hawkins, Schubert \& Thomas. 'Nutrition in childhood. In:Krause's. Food, Nutrition \& Diet Therapy'. 2009; Vol.11: 226-232

21. Emalia, Fatmalina, F., dan Anita, R. Hubungan Asupan Gizi, Pengetahuan Dan Stimulasi Ibu Dengan Tumbuh Kembang Anak Prasekolah Tk Handayani Dan Tk Teratai 26 Ilir Kecamatan Bukit Kecil Palembang 2014. Jurnal Ilmu Kesehatan Masyarakat. 2015;Vol.6(1):23-30.

22. Iis,S., Rindit, P., dan Fatmalina, F. Gambaran Faktor-Faktor Yang Mempengaruhi Status Gizi Anak Umur 2-5 Tahun Pada Keluarga Petani Di Desa Pelangki Kecamatan Muaradua Kabupaten Oku Selatan. Jurnal Ilmu Kesehatan Masyarakat. 2012;Vol.3(2): 96-107.

23. Asrori, A. Hubungan Kecerdasan Emosional dan Interaksi Teman Sebaya dengan Penyesuaian Sosial pada Siswa. Skripsi. Universitas Sebelas Maret. 2009.

24. Edwards, M.J., dkk. The Influence of Friends and Siblings on the Physical Activity and Screen Viewing Behaviours of Children Aged 5-6 Years: A Qualitative Analysis of Parent Interviews. BMJ Open. 2015;Vol.5: 1-7.

25. Dewi, S.R. Hubungan Lama Menonton Televisi Terhadap Perkembangan Sosial Anak Usia 3-5 Tahun di Posyandu Mandiri Murangan VIII Triharjo Sleman Yogyakarta. Skripsi. Sekolah Tinggi
Ilmu Kesehatan Jenderal Achmad Yani. 2017.

26. Chen, A. Children and Television. London: Routledge. 2011.

27. Wahyu, G.G. Obesitas pada Anak. Yogyakarta: PT Bentang Pustaka. 2009.

28. Atif, A., dan Marsa, S.M.S. Bermain Lebih Baik daripada Menonton TV. Surakarta: Ziyad Visi Media. 2009.

29. Benson, L.J. The Role of Parental Employment in Childhood Obesity. Dissertation. University of Maryland. 2010.

30. Lindsay, A.C., dkk. The Role of Parents in Preventing Childhood Obesity. Spring. 2006; Vol.16(1): 169-186.

31. Griffith, J.R., dkk.Role of Parents in Determining Children's Physical Activity. World Journal of Pediatric. 2007;Vol.3(4): 265-270.

32. Savage, J.S., DiNallo, J.M., \& Downs, D.S.Adolescent Body Satisfaction: The Role of Perceived Parental Encouragement for Physical Activity. International Journal of Behavioral Nutrition and Physical Activity.2009; Vol.6(90): 1-8.

33. Davison, K.K, Cutting, T.M., dan Birch, L.L. Parents Activity-Related Parenting Practices Predict Girls Physical Activity. American College of Sport and Exercise. 2003; Vol.35(9): 1589-1595.

34. Mulyadi, S. Kekhawatiran Akan Generasi yang Hilang. Jakarta: Kompas. 2001. 